\section{National and International Approaches to Combat Cultural Heritage Trafficking in Post-2011 Egypt.}

Randa Alaa EI-Din Fouad

\section{Abstract}

Cultural heritage trafficking is globally recognized as an international threat and an obstacle against revealing the secrets of humanity's history. Today, the illicit trafficking of cultural property is reaching its highest levels, particularly in the MENA region, compelling the international community to increase its efforts to protect the region's cultural heritage from looting, pillaging, demolition, illegal transfer and illicit trafficking.

With reference to Egypt, the Egyptian authorities have lately multiplied their efforts, particularly after the 2011 and 2013 revolutions, on the national and international levels aiming to foil the illicit trafficking of cultural property, thus demonstrating its long-term commitment to the protection of the nation's heritage. This article mainly aims to highlight the exerted governmental efforts to protect and safeguard the Egyptian cultural heritage from illicit trafficking. It also demonstrates the recently adopted governmental approaches to combat all aspects of trafficking in cultural property. Additionally, it sheds the light on the deep need for further national and international cooperation to tackle cultural heritage trafficking, looting and smuggling issues.

\section{Keywords}

illicit trafficking, cultural property, looting, illegal excavations, smuggling, national efforts, international cooperation.

\section{Introduction}

Looting of art and antiquities is globally known since prehistory till nowadays during wars or in conflict zones, whether to indicate vitory over the defeated, to obtain spoils of war or to generate money hrough their illegal trade.

The illicit raflicking of drugs. ${ }^{2}$ It is increasingly linked with money laundering, funding terrorism and organized crime. ${ }^{3}$ Moreover, it has been identified by the INTERPOL (International Criminal Police Organization) as a serious transnational crime affecting all regions around the world. ${ }^{4}$ Indeed, cultural heritage trafficking has grown widely around the basic concepts of supply and demand. The increasing demand for cultural artifacts has resulted in the development of a wealthy art and antiquities market with an international dimension. ${ }^{5}$ In effect, wealthy countries with high demand of cultural artifacts are of short supply of cultural heritage, i.e., UK, USA, Switzerland, Japan, Sweden and France, while the supply side of art and antiquities market represents the poorer countries, i.e., Egypt, Iraq, Cambodia and Mexico. ${ }^{6}$ As a transnational crime, illicit antiquities trade goes from "source" countries to "market" countries, where artifacts are displayed at museums or owned as private collections, through passing by
"transit" countries.

Noah Charney, "A History of Transnational Trafficking in Stolen and Looted Art and Antiquities," in Histories of Transnational Crim, ed. Gerben Bruinsma

2 Marc-André Renold, "The Legal and IIlegal Trade in Cultural Property to and throughout Europe: Facts, Finds and Legal Analysis," " paper presented at the http://www.unesco.org / new/fileadmin/MULTIMEDIA/HQ/CLT/images/630X300/Study_Prof_Renold_EN_02.pdf [Accessed on 23 September 2019

3 UNESCO, "Fighting the IIlicit Trafficking of Cultural Property," http://www.unesco.org/new/fileadmin/MULTIMEDIA/HQ/CLT/movable/pdf/

4 INTERPOL, "Protecting Cultural Heritage Through Interagency Cooperation," https://www.interpol.int/News-and-Events/News/2019/Protecting-
cultural-heritage-througah-interagency-cooperation [Accessed on 23 September 2019. (A)

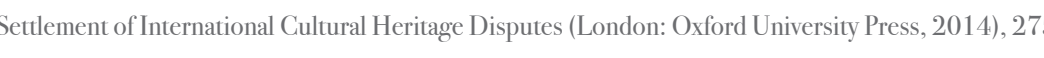

(London: Routledge, 2012), 137

7 Brigitta Hauser-Schäublin and Lyndol Prott, Cultural Property and Contested Ownership: The Trafficking of Artefacts and the Quest for Restitution
Randa Alaa FL-Din Fouad

Since the 1970 s, there has been a tendency to combat trafficking in cultural property around the world. A substantial number of international conventions and soft law agreements were adopted aiming to control and eliminate the illegal trafficking of art, antiquities and cultural property. One of the main instruments is the 1995 UNIDROIT (International Institute for the Unification of Private Law) convention on stolen or illegally exported cultural objects. ${ }^{8}$

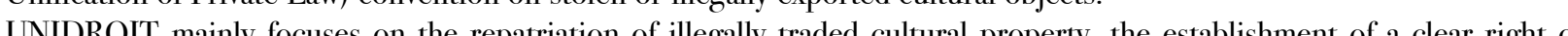

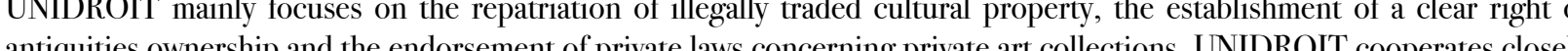
with a numer of Scientific Cus Ore ICOM (Into Council. $^{9}$

The international cooperation in the field of cultural heritage protection was reinforced with the launch of the Academic Project (UCAP), on 27 October 2017, which secks judges, ol 270 rop providinginformation about the 1995 Convention. ${ }^{10}$ As part of a joint initiative with the European Union, UNESCO introduced two new tools, in March 2019, to help the judiciary and law enforcement agencies fight the illicit trafficking of cultural property. The first tool is known as the «Toolkit for European Judiciary and Law Enforcement" which aims to provide a range of answers to professionals combating this type of organized criminal activity. In addition to the Toolkit, UNESCO developed an e-learning platform offering step-by-step training to provide an understanding of how this type of organized crime works and explains how to use legal and practical tools to fight it more efficiently and effectively. Moreover, it enables judiciary and law enforcement professionals to learn about different key concepts and special investigative techniques and to exchange information and ideas with their colleagues from allover Europe. ${ }^{11}$

The Arab Spring uprisings of 2011 served as a catalyst for the systematic looting and illicit trade of antiquities in the MENA region, including Egypt, either by the local population or organized criminal oroups. ${ }^{12}$ In particular, the aftermath of the Egyptian 2011 and 2013 revolutions urged the Egyptian governmental authorities with the assistance of both private and public sectors to develop and articulate new approaches and visions concerning the protection and safeguarding of cultura heritage from illicit trafficking, negligence, looting, smugroling, vandalism and illegal encroachments on both national and international levels.

\section{National and Local Approaches}

- In March 2011, the SCA (Supreme Council of Antiquities) issued a long list featuring the missing objects, resulted from the attack of the Egyptian Museum at Tahrir on 28 January 2011 , to raise public awareness and encourage vigilance. ${ }^{13}$ Citizen were able to recover more than $70 \%$ of the looted artifacts. Undoubtedly, the spontaneous attitude of the young Egyptians, who formed a human shield to protect the Egyptian Museum from further theft, reflected the strong commitment between the new generation of the Egyptians and their estimated unique heritage. It should be mentioned that the revolution has had its positive side-effect of inspiring local interest in Egyptian heritage and consequently the number of Egyptian visitors to the provincia museum has risen exponentially. ${ }^{14}$

-A substantial number of national campaigns were launched seeking the involvement of the locals to clean up the heritage

8 Annelies Pauwels, "SSis and Illicit Trafficking in Cultural Property: Funding Terrorism through Art," Freedom from Fear Magazine, August 1, 2016

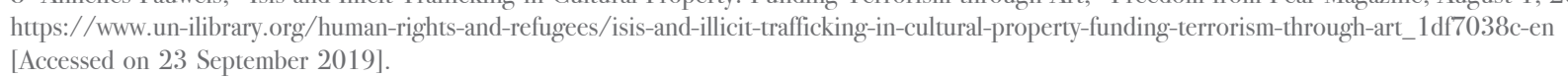
9 UNIDROIT, "UNIDROIT Work and Instruments in the Area of Cultural Property," https:// /www.unidroit.org/cultural-property [Accessed on 28 Februar

10 UNIDROIT, “The 1995 UNIDROIT Convention Academic Project," https:// 1995unidroitcap.org/about-us/ [Accessed on 28 February 2019]. 11 UNESCO, "New UNESCO Tools to Fight the Illicic Trafficking of Cultural Property," March 15, 2019, htpp://www.wcoomd.org/en/media 12 Renold, "The Legal and Illegal Trade.

13 Suzie Thomas, "Egyptian Museum in Cairo-Theft and Recoveries in 2011," Trafficking Culture, 21 August, 2012, https://traffickingculture.org

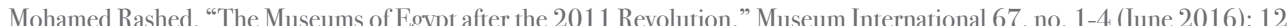


Vational and International Approaches to Combat Cultural Heriage Trafficking in Post-2011 Egypt

sites all over Egypt after the revolutions of both 2011 and 2013. For instance, the Dahshour community, in early April 2013, oroanized an event that aimed to raise the local awareness about environmental issues in the area. Several schools from Dahshour participated in the event, organizing a garbage collection rally through the villages, the lake, and the surrounding necropolis, planting trees and performing animation activities with their parents. ${ }^{15}$

- Other campaigns, provided with professionals from the heritage and museum sectors, were introduced to monitor heritage sites and museums especially during the times of conflicts such as the campaign led by Monica Hanna in 2013 known as "Egypt's Heritage Task Force". ${ }^{16}$

- Several campaigns were triggered after the Egyptian revolutions of 2011 and 2013 to combat the hard attacks and the deliberate destruction of the historical buildings all over the country. The renowned campaign of "Save Cairo", launched by Cairo Library in 2018, mainly focused on the demolition and negligence activities of heritage buildings in historic Cairo and to obtain governmental decisions to halt the demolition procedures especially in the area of Al-Darb Al-Ahmar, which contains about 65 ancient Islamic and mediaeval structures and severely suffered from the savagery that was ruining its old alleyways. ${ }^{17}$ - Following the constant attempts to save and restore Egypt's lost architectural heritage, Cairo Library kicked off "Welad ElBalad Heritage Campign" which aimed to raise people's awareness of mintining the nation's lost identity represented in Balad Heritage Campaign "Which similarly designed buildings. The compaign included hosting the Middle East's first regional conference on the role of he prot cion of (1)

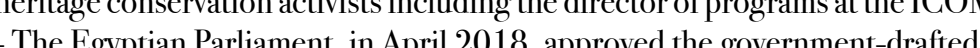

ded law that amends some provisions of Law No. 117 of 1983, as amended by law no. 3 of 2010, «Protection of Antiquities Law» to combat the illicit trade in antiquities. ${ }^{19}$ This updated legislative gives the SCA the responsibility to remove violations found at archaeological sites and set regulations for the activities on these sites with the assistance of the police, only as a safeguarding agency, while executing the council's decisions. According to article 42 and 45 of the drafted law, whoever steals, possesses, hides and collects antiquity for the purpose of smuggling or is involved in such action shall be punished with 25 years of imprisonment and a fine not less than LE 50,000 and not more than LE 250,000. The penalty of smugroling of illicit antiquities can extend to life imprisonment and a fine of LE100,000 to 500,000. The punishment of stealing or aiding in the robbery of a genuine artifact or piece of a monument or deliberately disfiguring artifacts or monuments is 15 years imprisonment and a fine of LE 50,000 to 100,000. The writing of graffiti or affixing of billposters and billboards to walls of monuments leads to detention from 6 to 12 months or a fine of $\mathrm{LE}$ of graffitit or affixing of billposters and billboards to walls of monuments leads to detention from 6 to 12 months or a fine of LE
150,000 . Additionally, article 30 of the drafted law indicates that the SCA is the only authority responsible for carrying out restoration and preservation work for all Egyptian monuments, archaeological sites and historical edifices. Correspondingly, the minister of culture will have the authority to assign any scientific mission to execute such work but under the complete supervision of the SCA. ${ }^{20}$

Egyptian buildings of architectural value and historical importance are protected by law No. 117/1983, amended by law no. 3 of 2010, law No.178/1961 and law No. 144/2006. ${ }^{21}$ The number of heritage buildings in Egypt is estimated at 6500 with 1163 heritage buildings in Cairo Governorate. The ambiguous legal jargon of the aforementioned laws led indirectly to the demolition of the heritage and historic buildings. Accordingly, around $75 \%$ of these buildings were lost and demolished between 2011 and 2014.22 The Egyptian parliament discussed the approval of the amendments of some of the provisions of

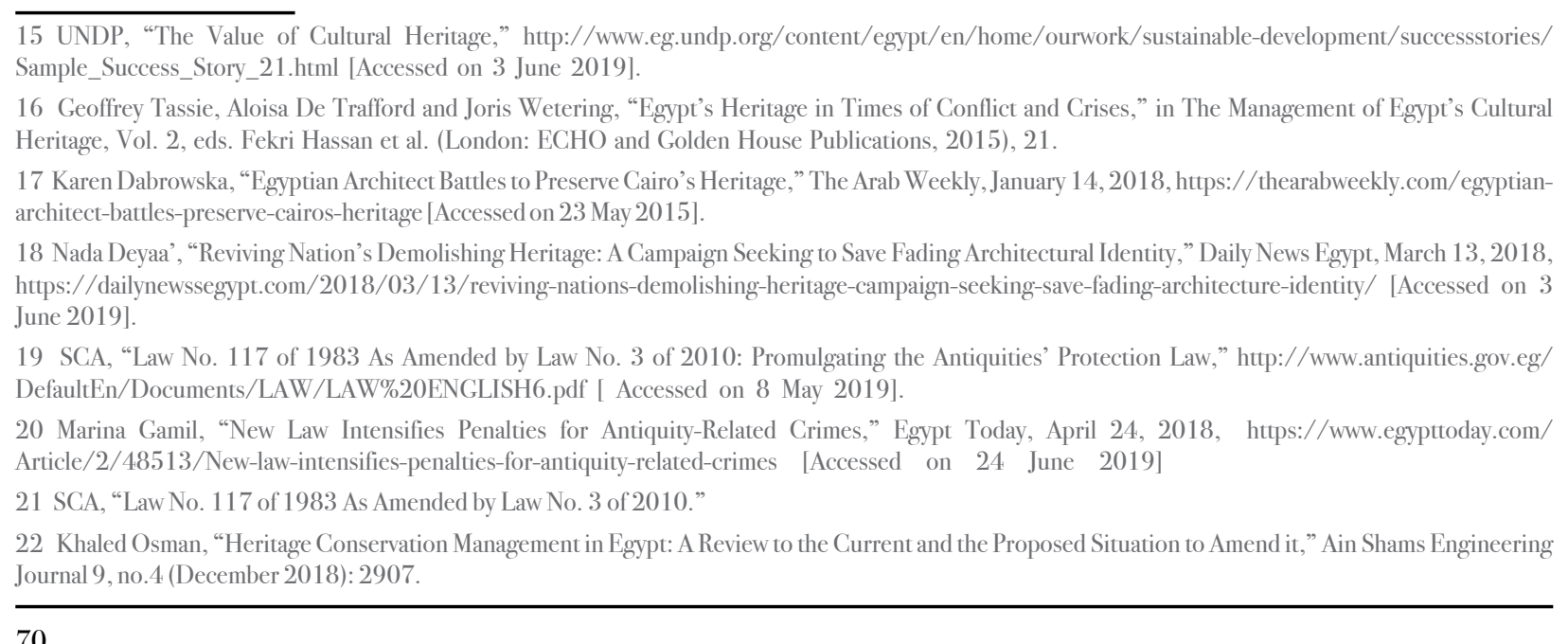

law No. 144/2006 to frame a better classification for heritage buildings, regulate the demolition of non-dilapidated building and control the establishments and the preservation standards of architectural heritage. ${ }^{23}$

- Workshops, awareness campaigns and symposiums were organized by different NGOs seeking to raise the local community's awareness of the importance of protecting and preserving cultural heritage. The most recent of which is the workshop held by the ER (Lgptian Heritage Rescue Foundation) in cooperation with the CULTNAT (Center for Documentation of Cultura Children Library of Bibliotheca Alexandrina in June 2019. The workshop essentially focuse

\section{International Approaches}

- Recent events, particularly in the MENA region, provoked an international considerable dialogue concerning the protection of cultural heritage during the time of civil unrest, armed conflicts and natural and other human-made disasters. ${ }^{25}$ Hence, the international communities such as the UNESCO and other actors developed international conventions and national laws and legislations to fight the post-colonial and clandestine trafficking of artifacts and antiquities. UNESCO continues to rely on the input and expertise of its principal partners in this field, namely the WCO (World Customs Organization), UNIDROIT, INTERPOL, UNODC, and ICOM. ${ }^{26}$

- UNESCO, with the assistance of its partner ICOM, sent a group of experts to Cairo from 21 to 25 March 2011. The special missions objectives were to assess the needs of the museum sector and to establish contact with the Egyptian authorities in order to continue the work on the protection of Egyptian cultural heritage. ${ }^{27}$

- From 3 to 13 May 2011, two experts were sent by UNESCO, including a representative from the INTERPOL, to assess the security measures taken in Egypt to protect the Egyptian museums and the cultural heritage sites up and down the country. The experts provided advice on how to enhance the Egyptian security measures to better protect the museums from being looted and sites from being illegally excavated in order to minimize the risks of illicit trafficking of Egyptian cultural property. This mission was an opportunity to collect information on the missing or stolen cultural objects during the revolution and onward and they were eventually included in the INTERPOL Works of Art Database. ${ }^{26}$

- UNESCO, with co-funding from the Federal Office for Culture of Switzerland, implemented, in November 2013, a series of capacity-building training courses and awareness-raising activities to focus on preventive actions on the fight against illici trafficking of cultural property in Egypt. Primarily, these projects aim to provide Egyptian heritage professionals with skills an knowledge to respond rapidly and effectively when addressing cases of illicit trafficking. An outcome of these comprehensive projects is the participation of the newly UNESCO trained Egyptian heritage rescue team who intervened rapidly at the Museum of Islamic Art, on 30 January 2014, after its bombing.

- The fulfillment of the previously mentioned training courses and awareness-raising campaigns was complemented by the educational program started by UNESCO in partnership with the Ministry of Education. This program targets the loc communities and youth who will be invited to get involved in safeguarding Egypt's heritage and to be aware of the damage resulted from the looting of cultural heritage and thus its versatile impacts on the Egyptian identity.

- The establishment of the EHRF, in 2013, with the objective of promoting and safeguarding Egyptian and regional cultura heritage. The foundation aims to offer courses relevant to Disaster Risk Preparedness and First Aid to Cultural Heritage (FACH) in cooperation with ICCROM and Athar regional center at Sharjah, which helped in translating the courses' materials intoArabic. ${ }^{31}$

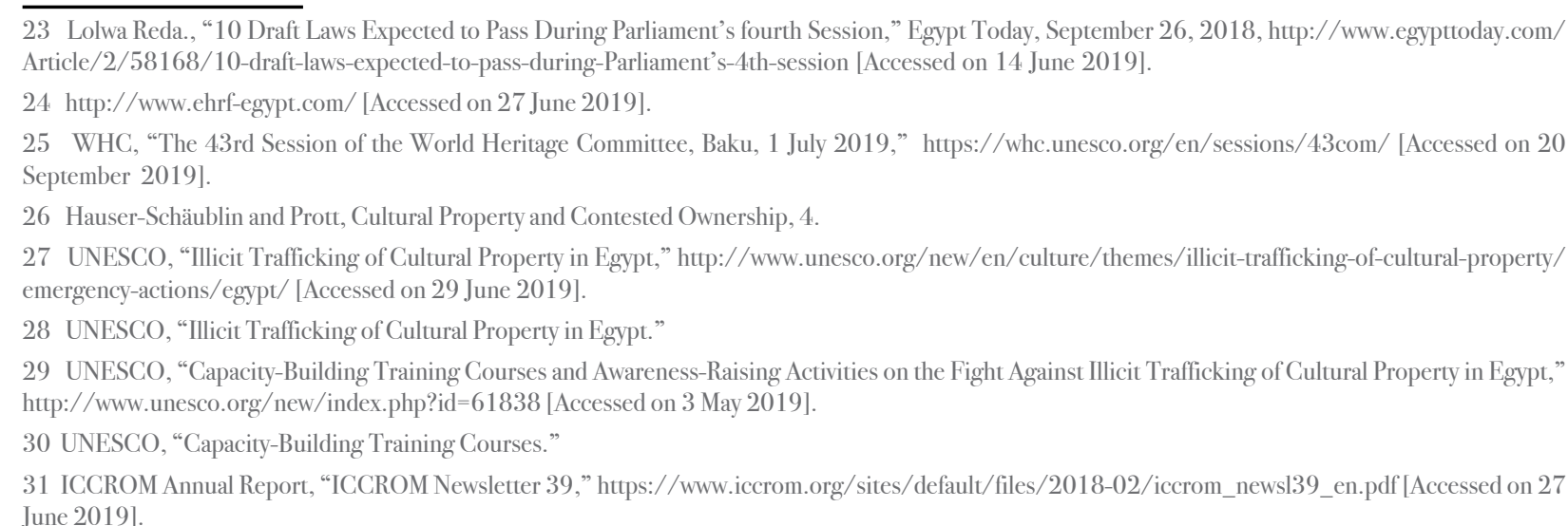
31 ICCROM Annual Report, "ICCROM Newsletter 39," hthps://www.iccrom.org/sites/default/files/2018-02/iccrom_newsl39_en.pdf [Accessed on 27
June 2019]. 
Vational and International Approaches to Combat Cultural Heriage Trafficking in Post-2011 Egypt

- The Swiss- funded project "Museum disaster preparedness and risk mitigation in the event of man-made disaster or conflict" was developed from 15-30 December 2013 and attended by 21 curators from different museums all over Egypt. The course aimed to develop risk preparedness and security management strategies for Egypt's museums as a tool for the efficient protection of cultural heritage, and prevention of looting or any other kind of risk during political instability, civil unrest and conflict. ${ }^{32}$ - A workshop was held from 31 March to 2 April 2014 in Cairo and organized by the UNESCO office in Cairo and UNESCO headquarters in Paris. The workshop particularly emphasized on the need for further training of national professionals involved in the fight against illicit trafficking of cultural property and how to improve cooperation with intergovernmental organizations as well. Moreover, it focused on maintaining and strengthening contact and cooperation between different stakeholders on national and international levels. It is worthy to mention that this workshop was the triggering point of a wider series of comprehensive projects led by UNESCO within the framework of global efforts to protect Egypt's unique cultural heritage, aimed at building the capacities of Egyptian heritage professionals through a range of targeted legal and operational training workshops, and awareness-raising activities. ${ }^{33}$

Marking the $10^{\text {th }}$ anniversary of archaeologists' day, the Ministry of Antiquities opened the temporary exhibit entitled, "Repatriated Objects: 2014-2015" at the Egyptian Museum in Tahrir Square. The exhibition celebrated the repatriation of about 500 Egyptian artifacts from eight foreign countries between 2014 and $2015 .{ }^{34}$

- In cooperation with the Ministry of Anipities and UAE and the U.S. Secretary State, A two-week specialist workshop on "Building National Capacities for Managing Risks Cul and Heritse in Case of Emergency" was launched in Cairo Egypt, on 29 Janury 2015. The workshop was organized Cultural Heritage in Case of Emergency "was launched in Cairo, Lgypt, on 29 january 2015 . The workshop was organized ay CCC Cultur - A two-day conference, held in Cairo in May 2015, focused on the of conflict. ${ }^{3}$

, focused on the protection of cultural heritage and ratifying an agreement Six recommendations were issued under the title "Cairo Declaration" to the means of protecting monuments from looting. purchasing of stolen antiquities. This conference was attended by UNESCO and ten Arab countries including Foypt Iraq Jordan, Libya, Sudan, Lebanon, Saudi Arabia, the United Arab Emirates, Kuwait and Oman. Thus, UNESCO announced the triggering of its campign: "\#Unite4Heritage" from the Museum of Islamic Art, coinciding with the start of the cultural heritage conference. The campaign aims to build an alternative to violent extremist narratives, based upon the ideals of cultural diversity, tolerance and understanding. ${ }^{36}$

- In the light of UNESCO partners' international support, an Egyptian-European conference was held on cultural heritage protection and prevention of cultural heritage stolen goods trafficking. The conference took place at the French Institute in Cairo from 8 to 9 March 2016. Representatives from heritage and museums' sectors attended the conference to discuss and share good practices to curb smuggling and illicit trafficking of cultural property.

The Egyptian Ministry of Antiquities with the assistance of UNESCO held an exhibition on seized antiquities on Egyptian ports at the Egyptian Museum in Tahrir square from 24 October to 15 December 2016. Around 300 rare objects, chosen from thousands of artifacts that were seized in previous vears, were displayed within the proceedings of the exhibition. Principally, the exhibition highlighted the efforts carried out by the Egyptian Ministry of Antiquities and all its units that are present at the air, land and seaports of Egypt, to protect Egyptian and world cultural heritage and prevent its smuggling out of Egypt. These efforts included examination, inspection and confiscation of objects, as well as following up on cases of seized objects, starting with the moment the objects were seized at the Egyptian ports, through their handling over to customs storehouses and

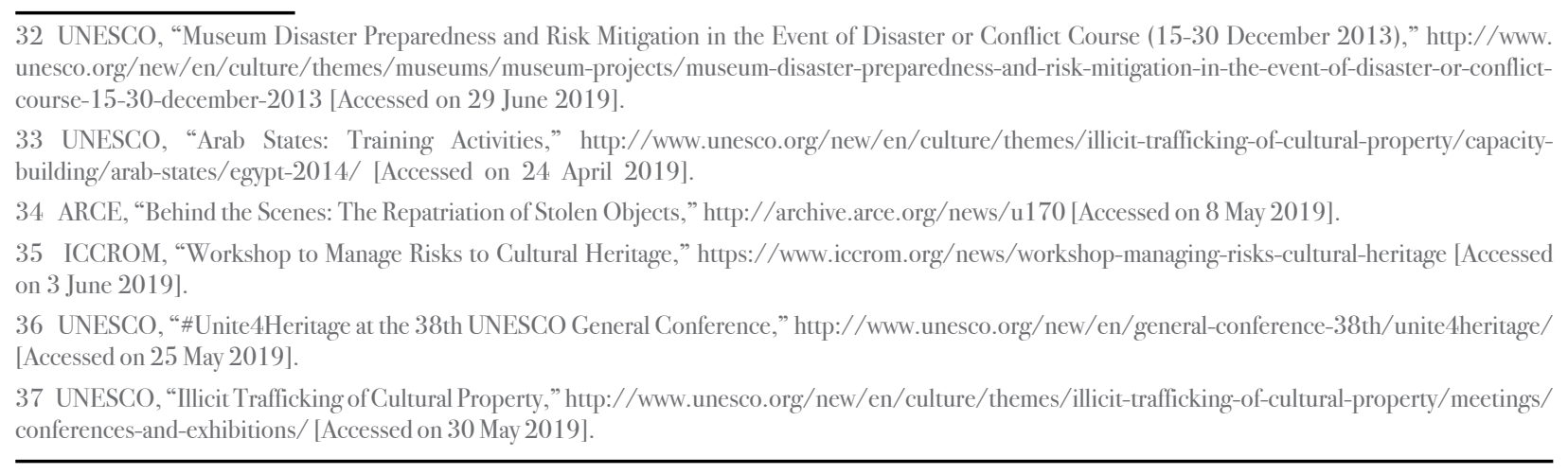

Randa Alaa Fl-Din Fouad

specialized prosecutions, and up until their deposit in the Ministry of Antiquities storages. ${ }^{38}$

- The U.S. government, in December 2016, signed for the first time a bilateral agreement with the Egyptian government to thwar illegal trade in antiquities. This action was complemented with the assistance of the HSI (Homeland Security Investigations) US, Ling range of crimes hat thra

- The Egyptian authorities succeeded in repatriating some artifacts, originated in Saqqara, on the e-catalog of the French auction rest

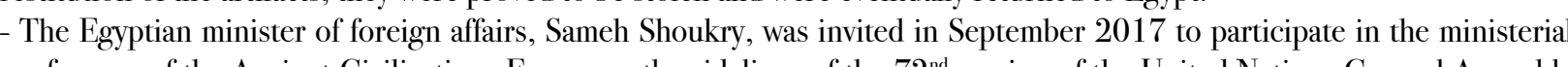
(U) $72^{\text {nd }}$ session of the United Nations General Assembly (WNe importance of countering illicit trafficking in cultural property - The WCO in cooperation with the INTERPOL and UNESCO reged conflicts including Egypt, Syria, Iraq and Libya. ${ }^{4}$ including $\mathrm{Eghp}$ a of cultural objects and dedicated tools and instruments, developed by the WCO, INTERPOL ICOM and other internationg pars fromplundering. ${ }^{2}$.

- The Egyptian authorities repatriated eight Egyptian artifacts, dating back to the first millennium B.C, after they have been illewally exported to France in 2010. The investiontions revealed that these objects were smuroled through an organized (1) artifacts were returned after negotiating with the French government concerning their restitution. ${ }^{43}$

- The DAAD regional office in Cairo held a three-day COSIMENA Heritage Cluster conference from 7 to 9 May 2018 - The DAAD regional office in Cairo held a three-day COSINENA Heritage Cluster confrence from 7 to 9 May 2018 Leading experts from the fields of heritage, history, museology, archaeology and geology around the MENA region attended identify, analyze, document and keep elements of cultural heritage safe for future generations ${ }^{4 t}$

- In July 2018, the Egyptian authorities repatriated nearly 1,000 antiquities that were smuggred to Switzerland, UAE, Italy, USA, Belgium, Mexico and Austria. Most recently, the Italian Antiquities and Tourism Police informed the Eoyptian embassy in Rome on 14 March that they had seized in Naples 23,700 artifacts, including 118 ancient Egyptian items that ultimately went on display at the Egyptian Museum. 45

- Egypt was elected, as the first Arab country since 2013, to chair the UNESCO subsidiary committee of the 1970 convention for countering the illicit trafficking of cultural property for the period from May 2018 till May 2019. The unanimous election reflects the appreciation of the convention's member states of the latest efforts exerted by Eoypt to prevent the illicit trafficking of cultural property and to repatriate its stolen antiquities. ${ }^{46}$

- Trainers from the U.S. Department of HIS, the FBI (Federal Bureau of Investigations), and the Cultural Antiquities Task Force at the U.S. Department of State joined Egyptian officials from the Ministry of Antiquities, Egyptian Customs, Touris

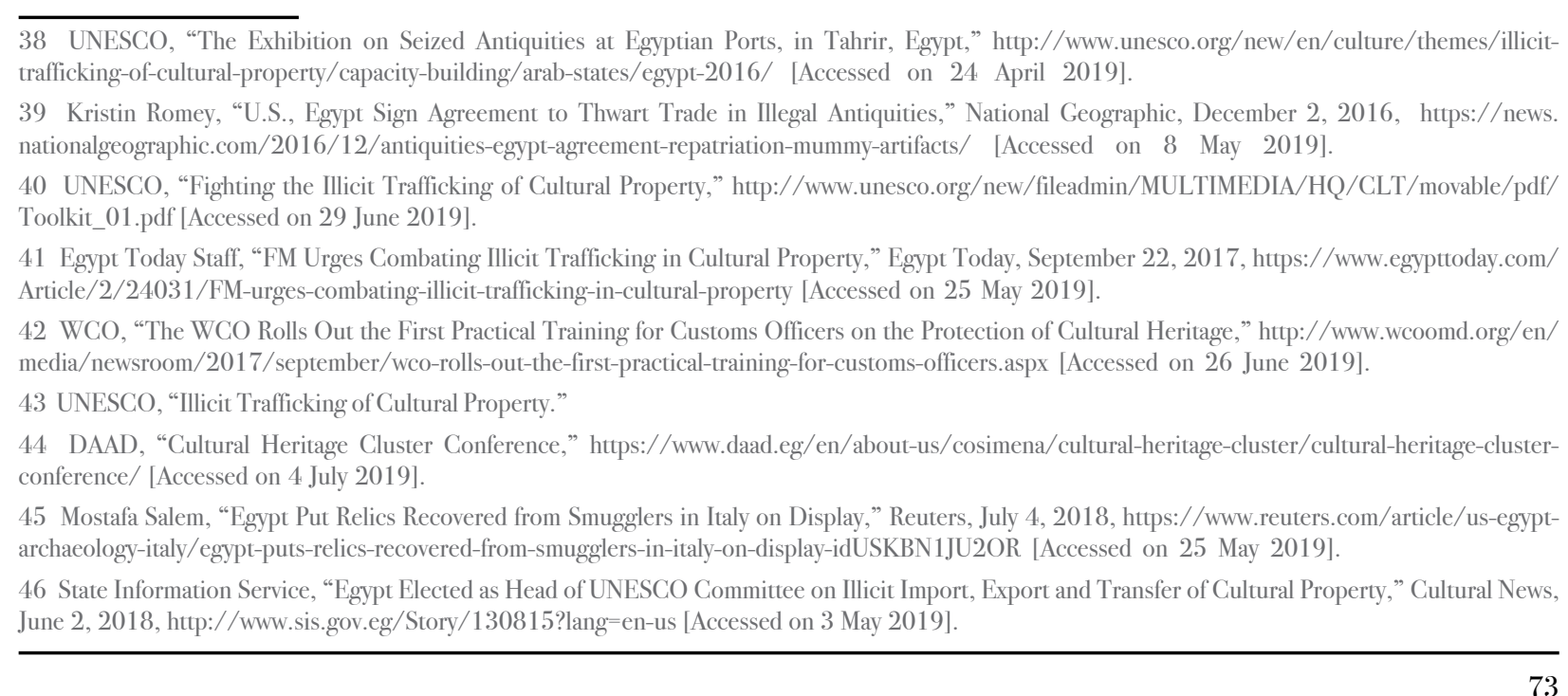


Police, and other agencies organized the first WCO Middle East and North Africa (MENA) Train-the-Trainer Session for Customs officers on the prevention of illicit trafficking of cultural objects, which was held from 18 to 21 September 2017. Customs agencies, in September 2018, to attend a week-long workshop organized by the U. S. embassy in Cairo. The workshop discussed how the two countries can cooperate more effectively to protect cultural property, investigate cases of illegally exported antiquities and prevent the illicit trade of Egyptian and American antiquities. ${ }^{47}$

- The Egyptian Ministry of Antiquities announced the recovery of a tablet carved with the cartouche of king Amenhotep I. It is not exactly identified when the tablet was illegally smuggled, however, it was previously displayed at the Karnak open-air museum and later found in an unnamed London auction house. The Egyptian Ministry of Antiquities, the Egyptian Ministry of Foreign Affairs, the Egyptian Embassy in London and the British authorities cooperated closely and succeeded in repatriating the tablet in January 2019.48

The illegally trafficked gilded coffin of Nedjemankh, a high ranking ancient Egyptian priest, was returned to the Egyptian authorities 25 September 2019 at or No

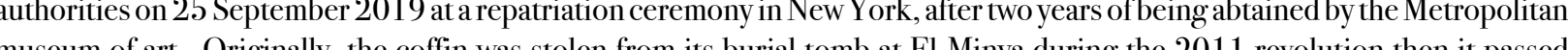
through UAF shipped to Cermany and transported hater to France. The coffin was sold to the Metropolitan museum in 2017 for a fee of $\$ 4$ million, using fake import papers and fored 1971 Egyptin export license. It is believed that the coffe will be or a fee or $\$$ 4 hion, using fake import papers and forged 1971 Egyptian export license. It is believed that the coffin will be

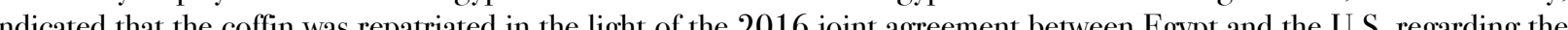
protection of the Egyptian antiquities. ${ }^{50}$

\section{Key Actions and Recommendations}

- A national network of stakeholders should be established to coordinate efforts for the fight against the illicit trafficking of cultural properties in Egypt. Government authorities, representatives from international organizations as well as art markets and auction houses should accede to police and customs officers, lawyers, museum directors and UNESCO experts to review challenges, identify actions and share good practices to combat cultural heritage smuggling. Moreover, experts, researchers, universities' professors and students should get involved in the research and documentation process of the cultural assets which is essential for the protection of cultural property.

- National inventories of cultural properties, notably for the movable objects, should be regularly updated in order to combat their illicit trafficking. Assorted inventory tools are available to help individuals and institutions to register and manage their collections. For instance, the ICOM created Red Lists for cultural objects at risks, which are practical tools to curb the illeomal traffic of cultural objects as they help individuals, organizations and authorities, such as police or customs officials, identify objects at risk and prevent them from being illegally sold or exported. Furthermore, the use of an international digital database of stolen cultural goods is another crucial requirement to identify the stolen objects, track them, prevent their transaction and finally their restitution.

- National legislations should include a clearer definition for cultural property and its state of ownership since the absence of these provisions may result in losing the right to repatriate the trafficked cultural goods. Consequently, the security level around museums and heritage sites should be increased and the export control regulations should be enhanced in the source around museums and heritage sites should be increased and the export control regulations should be enhanced in the source destination countries, cooperation on antiquities' repatriation, market monitoring, firm trade regulations and effective import controls are highly required to thwart and eliminate illicit trafficking of cultural heritage..$^{5}$

- National conferences, seminars and capacity building workshops should be convened on the protection of cultural heritage to strengthen capacities for the fight against illicit trafficking of cultural heritage property. These practices should emphasize

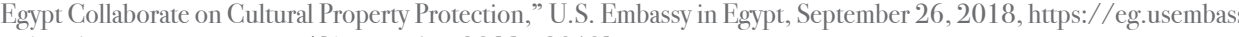
7v.S.-Mission Egypl,

48 Chloe Taylor, “Ancient Egyptian Artefact Returned after Being Smuggled to London Auction House," CNBC, January 9, 2019, https://www.cn $\mathrm{mm} / 2019 / 01 / 09 /$ ancient-egyptian-artefact-returned-affer-being-smuggeled-to-london.html [Accessed on 27 June 2019

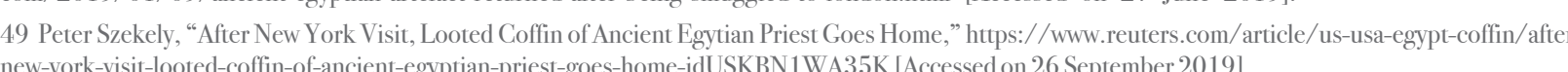

0 Mira Maged, "US Returned Loteed 2,100-Year-Old Coffin of nedjemankh to Egypt," https://www.egyptindependent.com/us-returns-back-to-eg

SCO, "Fighting the Illicit Trafficking of Cullural Property."
Randa Alaa Fl-Din Fouad

fundamentaly on the implementation of the "UNESCO 1970 Convention for the fight against illicit trafficking of cultura property" and offer the participants the opportunity to acquire knowledge about the benefits of ratification of the 199 "UNDRO " Further inter parted Tadan inner safeguarding cultural heritage property through the involvement of the local communies in heritage the archaeological and historical sites, whom they are living next to, so they can assist in locating the sites and be awse the importance of its protection as well. Forums, symposiums, events, study-days and workshops should be organized on larger seale to forge links between the civil society and experts, acadenia, researchers, policy makers and students to be on ace conscious of the value and sinificance of their culural heritage. Furthermere they public awareness over the grave threats of illicit cultural heritage traffickingand its impat on the Egyptian cultural identity It noteworty here to fer to the ole of site manarement. It also offers a better understanding of the identifiction and empowerment of communities since the recognition of the role of the loct accordingly get involved in the decision-making process. This role is highlighted through the strategic objectives of the World Heritage Convention for the "Five Cs". Credibility, Conservation, Capacity Building, Communication and Commuitie (JokilehtoJ., 2017). ${ }^{52}$

-With a view of protectingthe Egyptian cultural heritage from being illicitly trafficked across the borders, an effective partnership and cooperation between Eoypt and the relevant international and regional orranizations such as UNESCO, ICOM. WCO, INTERPOL and UNES (United Nations Office on Druos and Crime) is needed to provide customs' officers with wide and flexible range of activities. In this regard, capacity building workshops and training programs should be held to increase the preventive measures recommended by the 1970 UNESCO Convention on the Means of Prohibiting and Preventing the Illici Import, Export and Transfer of Ownership of Cultural Property to combat all aspects of smuggling of cultural heritage goods. - The deep need for the Eoyptian government to sign supplemental bilateral and multilateral aoreements with foreign countries for mutual assistance in criminal, concerning the repatriation of looted Egyptian antiquities. Moreover, the process of for mutual assistance in criminal, concerning the repatriation of looted Egyptian antiquities. Moreover, the process of an international dimension. Subsequently, negotiation channels should be conducted between the Foyptian authorities, the NGO's and the international community for restrictions on antiquities smuggling and illegal trade.

-The importance of exploring cooperation and coordination opportunities among the relevant international and regiona organizations as UNESCO, INTERPOL, UNIDROIT, ICOM, ICOMOS, ICCROM, WCO and other foreign institutions and organizations, with permanent base in Egypt, to develop the proper mechanism to counter the hazardous impacts of illicil trafficking of cultural property in the MENA region, and specifically Egypt. 


\section{Conclusions}

Apparently, combating the destruction of cultural heritage and illicit trafficking of cultural property has become a priority for the Egyptian government, particularly after the revolutions of 2011 and 2013 . Thus, national and international efforts endeavored to increase the protection of the Egyptian cultural property from illicit trafficking not only for their economic values but also for their significant influence on the world's cultural diversity which can be potentially devastating in case of their loss.

The recent Egyptian governmental efforts indicate an assertive international movement to thwart the smuggling of cultural goods and to recover the stolen artifacts. However, in view of what has been mentioned so far, it is noticeable that the Egyptian authorities paid great attention to fight against the threat ofillicit trafficking of cultural property on the international levels rather than the local ones. While national cooperation constitutes one of the most effective means for protecting the country's cultural heritage property, several local challenges still impede the implementation of a sustainable national strategy for combating the licit trafficking of cultural goods.

In this regard, preventive measures and systematic practices to respond to this transnational crime should be discussed in coordination with relevant national agencies, international organizations, private sector and educational institutions. Moreover, national approaches appear to require further efforts, measures and development which cannot be fulfilled without the agreement and the support of the public, with a change in their common mind-set, on considering illegal trade of cultural property as a serious crime

\section{Bibliography}

-ARCE. "Behind the Scenes: The Repatriation of Stolen Objects," http://archive.arce.org/news/u170 [Accessed on 8 May 2019].

-Charney, Noah. "A History of Transnational Trafficking in Stolen and Looted Art and Antiquities." in Histories of Transnationa Crim,edited by Gerben Bruinsma, 103-146. London: Springer, 2015

-Chechi, Alessandro. The Settlement of International Cultural Heritage Disputes. London: Oxford University Press, 2014. -DAAD. "Cultural Heritage Cluster Conference." https:// www.daad.eg/en/about-us/cosimena/cultural-heritage-cluster/ cultural-heritage-Cluster-conterence/

-Deyaa' Nada "Reviving Nation's Demolishing. Heritage: A Campe Accessed on 23 May 2015]. Daily News Egypt, March 13, 2018. https://dailynewssegypt.com/2018/03/13/reviving-nations-demolishing-heritagecampaign-seeking-save-ading-architecture-identity/ [Accessed on 3 June 2019].

-Egypt Today Staff. "FM Urges Combating Illicit Trafficking in Cultural Property." Egypt Today, September 22, 2017 https://www.egypttoday.com/Article/2/24031/FM-urges-combating-illicit-trafficking-in-cultural-property_[Accessed of 25 May 2019

-Forrest, Craig. International Law and the Protection of Cultural Heritage. London: Routledge, 2012

-Gamil, Marina. "New Law Intensifies Penalties for Antiquity-Related Crimes." Egypt Today, April 24, 2018. htps://www egypttoday.com/Article/2/48513/New-law-intensifiles-penalties-lor-antiquity-related-crimes [Accessed on 24 June 2019 the Quest for Restitution. London: Routledge, 2017.

http://www.ehrf-egypt.com/ [Accessed on 27 June 2019].

-ICCROM. "ICCROM Newsletter 39." https://www.iccrom.org/sites/default/files/2018-02/iccrom_news139_en.pd

Accessed on 27 June 2019].
ICCROM. "Workshop to Manage Risks to Cultural Heritage." https://www.iccrom.org/news/workshop-managing-riskscultural-heritage [Accessed on 3 June 2019].

-INTERPOL. "Protecting Cultural Heritage Through Interagency Cooperation." https://www.interpol.int/News-andEvents/News/2019/Protecting-cultural-heritage-through-interagency-cooperation [Accessed on 23 September 2019] in Rauma: Living in World Heritage and Community Involvement. Finland, 11-14 September, 2017 htte / lettere unirome it/sites/default/files/Ilokilehto paper on\% 20 five\% $20 \mathrm{Cs} \% 20$ of $\% 20$ the\% $20 \mathrm{WHC} \% 2 \mathrm{C} \% 20$ communities\% 20 and $\% 20$ synergies\%20with\%20ICH.pdf [Accessed on 23 August 2019].

-Maged, Mira. "US Returned Looted 2,100-Year-Old Coffin of Nedjemankh to Egypt." https://www.egyptindependent.com/ us-returns-back-to-egypt-looted-2100-year-old-nedjemankh-coffin/[Accessed on 26 September 2019].

-Marc-André, Renold. "The Legal and Illegal Trade in Cultural Property to and throughout Europe: Facts, Finds and Lega

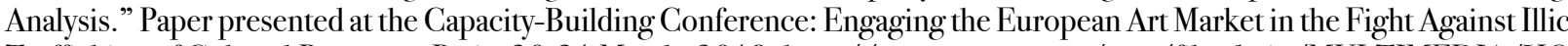
Trafticking of Cultural Property, Paris, 20-21 March, 2018, htp:// www.unesco.org/new/fleadmin/MULTIMEDIA/HQ CLT/images/630X300/Study Prof Renold EN 02.pdf FAccessed on 23 Seppember 2019]

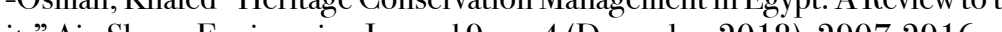

-Pauwels, Annelies. "Isis and Illicit Trafficking in Cultural Property: Funding Terrorism through Art." Freedom from Fear property-tunding-terrorism-through-art 1df7038c-en [Accessed on 23 September 2019]. 125-131.

-Reda., Lolwa. “10 Draft Laws Expected to Pass During Parliament's fourth Session.” Egypt Today, September 26, 2018 http://www.egypttoday.com/Article/2/58168/10-draft-laws-expected-to-pass-during-Parliament's-4th-session [Accessed on 14 June 2019].

-Romey, Kristin. “U.S., Egypt Sign Agreement to Thwart Trade in Illegal Antiquities." National Geographic, December 2 https://news.nationalgeographic.com/2016/12/antiquities-egypt-agreement-repatriation-mummy-artifacts/

-Salem, Mostafa. "Egypt Put Relics Recovered from Smugglersin Italy on Display." Reuters, July 4, 2018. https:/ / www.reuters. [Accessed on 25 Mav 2019 ].

-SCA. “Law No. 117 of 1983 As Amended by Law No. 3 of 2010: Promulgating the Antiquities' Protection Law." http:// www.antiquities.gov.eg/DefaultEn/Documents/LAW/LAW\%20ENGLISH6.pdir JAccessed on 8 May 2019). Property." Cultural News, June 2, 2018. htpp://www.sis.gov.eg/Story/130815?lang=en-us [Accessed on 3 May 2019]. 
-Szekely, Peter. “After New York Visit, Looted Coffin of Ancient Egyptian Priest Goes Home.” https://www.reuters.com/ article/us-usa-egypt-coffin/after-new-york-visit-looted-coffin-of-ancient-egyptian-priest-goes-home-idUSKBN1WA35K [Accessed on 26 September 2019].

-Tassie, Geoffrey, De Trafford, Aloisa and Joris Wetering. Egypt's Heritage in Times of Conflict and Crises. In The Management of Egypt's Cultural Heritage, Vol. 2, edited by Fekri Hassan et al., 14-47. London: ECHO and Golden House Publications, 2015.

-Taylor, Chloe. “Ancient Egyptian Artefact Returned after Being Smuggled to London Auction House.” CNBC, January 9, 2019. https://www.cnbc.com/2019/01/09/ancient-egyptian-artefact-returned-after-being-smuggled-to-london.html [Accessed on 27 June 2019].

-Thomas, Suzie. "Egyptian Museum in Cairo-Theft and Recoveries in 2011.” Trafficking Culture, 21 August, 2012. https:// traffickingculture.org/encyclopedia/case-studies/egyptian-museum-cairo-thefts-and-recoveries-in-2011/ [Accessed on 7 June 2019].

-U.S. Mission Egypt. "U.S. and Egypt Collaborate on Cultural Property Protection.” U.S. Embassy in Egypt, September 26, 2018. https://eg.usembassy.gov/u-s-and-egypt-collaborate-on-cultural-property-protection/ [Accessed on 20 May 2019]. -UNDP. "The Value of Cultural Heritage." http://www.eg.undp.org/content/egypt/en/home/ourwork/sustainabledevelopment/successstories/Sample Success Story 21.html [Accessed on 3 June 2019].

-UNESCO. "\#Unite4Heritage at the 38 ${ }^{\text {th }}$ UNESCO General Conference." http://www.unesco.org/new/en/generalconference-38th/unite4heritage/ [Accessed on 25 May 2019].

-UNESCO. "Arab States: Training Activities." http://www.unesco.org/new/en/culture/themes/illicit-trafficking-ofcultural-property/capacity-building/arab-states/egypt-2014/ [Accessed on 24 April 2019].

-UNESCO. "Capacity-Building Training Courses and Awareness-Raising Activities on the Fight Against Illicit Trafficking of Cultural Property in Egypt." http://www.unesco.org/new/index.php?id=61838 [Accessed on 3 Mav 2019].

-UNESCO. "Fighting the Illicit Trafficking of Cultural Property." http://www.unesco.org/new/fileadmin/MULTIMEDIA/ HQ/CLT/movable/pdf/Toolkit_01.pdf [Accessed on 29 June 2019].

UNESCO. "Illicit Trafficking of Cultural Property in Egypt." http://www.unesco.org/new/en/culture/themes/illicittrafficking-of-cultural-property/emergency-actions/egypt//Accessed on 29 June 2019].

-UNESCO. "Illicit Trafficking of Cultural Property." http://www.unesco.org/new/fileadmin/MULTIMEDIA/HQ/CLT/ movable/pdf/Toolkit 01.pdf [Accessed on 29 June 2019].

-UNESCO. "Illicit Trafficking of Cultural Property." http://www.unesco.org/new/en/culture/themes/illicit-trafficking-ofcultural-property/meetings/conferences-and-exhibitions/ [Accessed on 30 May 2019].

-UNESCO. "Museum Disaster Preparedness and Risk Mitigation in the Event of Disaster or Conflict Course (15-30 December 2013).” http://www.unesco.org/new/en/culture/themes/museums/museum-projects/museum-disaster-preparednessand-risk-mitigation-in-the-event-of-disaster-or-conflict-course-15-30-december-2013 [Accessed on 29 June 2019].

-UNESCO. "New UNESCO Tools to Fight the Illicit Trafficking of Cultural Property." March 15, 2019. http://www. wcoomd.org/en/media/newsroom $/ 2019 / \mathrm{march} /$ new-unesco-tools-to-fight-the-illicit-trafficking-of-cultural-property.aspx [Accessed on 7 April 2019].

-UNESCO. "The Exhibition on Seized Antiquities at Egyptian Ports, in Tahrir, Egypt." http://www.unesco.org/new/en/ culture/themes/illicit-trafficking-of-cultural-property/capacity-building/arab-states/egypt-2016/_Accessed on 24 April 2019].

-UNIDROIT. "The 1995 UNIDROIT Convention Academic Project." https://1995unidroitcap.org/about-us/ [Accessed on 28 February 2019].

-UNIDROIT. "UNIDROIT Work and Instruments in the Area of Cultural Property." https://www.unidroit.org/culturalproperty [Accessed on 28 February 2019].

-WCO. "The WCO Rolls Out the First Practical Training for Customs Officers on the Protection of Cultural Heritage." http:// www.wcoomd.org/en/media/newsroom/2017/september/wco-rolls-out-the-first-practical-training-for-customs-officers. aspx [Accessed on 26 June 2019].

-WHC. "The 43rd Session of the World Heritage Committee, Baku, 1 July 2019." https://whc.unesco.org/en/ sessions $/ 43 \mathrm{com} /$ 